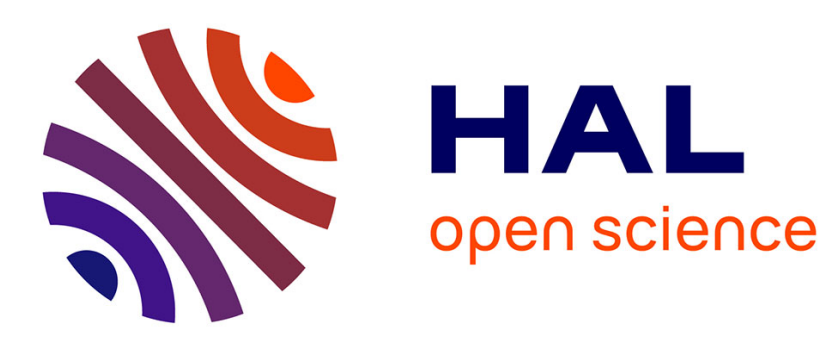

\title{
Trace element partitioning between wollastonite and alkaline silicate magmas
}

Céline Baudouin, Lyderic France

\section{To cite this version:}

Céline Baudouin, Lyderic France. Trace element partitioning between wollastonite and alkaline silicate magmas. Chemical Geology, 2019, 523, pp.88-94. 10.1016/j.chemgeo.2019.06.001 . hal-02383876

\section{HAL Id: hal-02383876 https://hal.science/hal-02383876}

Submitted on 3 Dec 2019

HAL is a multi-disciplinary open access archive for the deposit and dissemination of scientific research documents, whether they are published or not. The documents may come from teaching and research institutions in France or abroad, or from public or private research centers.
L'archive ouverte pluridisciplinaire HAL, est destinée au dépôt et à la diffusion de documents scientifiques de niveau recherche, publiés ou non, émanant des établissements d'enseignement et de recherche français ou étrangers, des laboratoires publics ou privés. 
2 Trace element partitioning between wollastonite and alkaline 3 silicate magmas

9 Céline Baudouin $^{1}$, Lydéric France ${ }^{1}$

$14{ }^{1}$ Centre de Recherches Pétrographiques et Géochimiques, UMR 7358 CNRS-UL, 15 rue 15 Notre Dame des Pauvres BP 20, 54500 Vandœuvre les Nancy, France

$24{ }^{*}$ Corresponding author: Céline Baudouin

25 Tel.: $+33(0) 383594877$

26 E-mail: baudouin.geol@gmail.com 

40 41

Abstract

The partitioning of trace elements between wollastonite and melt provides a choice tool for understanding differentiation processes and trace element fractionation in alkaline-rich and silica-undersaturated magmatic systems at crustal conditions, but very few data are currently available. Here we provide the first partition coefficients and associated lattice strain parameters between wollastonite and silicate magmas of Oldoinyo Lengai (Tanzania). Trace element partitioning of isovalent cations shows a parabolic dependence between the partition coefficients and ionic radii explained by the lattice strain model with the site radius $\left(r_{0}\right)$ decreasing with increasing charge from ${r_{0}}^{1+}=1.2 \AA$ to $r_{0}{ }^{5+}=0.6 \AA$. Bivalent cations are moderately incompatible $\left(D_{\mathrm{Mg}}=0.12\right.$ and $\left.D_{\mathrm{Sr}}=0.5\right)$ to compatible $\left(D_{\mathrm{Mn}}=1\right)$. High field strength elements such as $\mathrm{Zr}$ and $\mathrm{Nb}$ are strongly incompatible in wollastonite $(D<0.01)$, and rare earth element (REE) partition coefficients increase with decreasing ionic radius from $D_{\mathrm{La}}$ $=0.19$ to $D_{\mathrm{Lu}}=2.8$. The crystallization of wollastonite could eventually strongly influence REE fractionation (and more specifically the light-heavy REE ratios) during magmatic differentiation of alkali-rich foiditic melts and should therefore be considered to fully understand trace element evolution and partitioning in alkaline and silica-undersaturated magmas.

Keywords: Wollastonite; Rare earth element; partition coefficient; alkaline magmas

Introduction

Wollastonite $\left(\mathrm{CaSiO}_{3}\right)$ is a pyroxenoid chain silicate present in skarns, carbonatites, and associated silicate rocks (e.g., Eckermann, 1974; Gold, 1966; Matsueda, 1973; Melluso et al., 2004; Weisenberger et al., 2014; Whitney and Olmsted, 1998), and is a common phase in the Oldoinyo Lengai (OL) nephelinitic suite (Dawson, 1998; Dawson et al., 1996). Oldoinyo Lengai stratovolcano has two major cone-building stages, with wollastonite as a key mineral of stage II (combeite wollastonite nephelinite). In recent times, during the OL explosive eruptions (e.g., 1917, 1966, 2007-2008), wollastonite is commonly found within the scoriaceous lapilli (Dawson et al., 1992; Keller et al., 2010; Sharygin et al., 2012). Wollastonite crystals are also present in OL crustal cumulates (in ijolites that contain clinopyroxene + nepheline + Ti-garnet as major phases) where wollastonite is in equilibrium with the last interstitial melt, and is among the last minerals (with apatite) to crystallise 
(Dawson et al., 1995; Mollex et al., 2018) (Fig. 1a). Wollastonite is also reported or a common phase in other igneous alkaline provinces associated with carbonatitic systems (e.g., Braunger et al., 2018, Gold, 1966; Ruberti et al., 2012; Woolley et al., 1995; Zaitsev et al., 2012). Conditions of wollastonite crystallization and its stability fields have been constrained experimentally for alkali-rich nephelinite magmas at low temperature $\left(\leq 925{ }^{\circ} \mathrm{C}\right)$ and low pressure (<500 MPa) (Kjarsgaard, 1998; Kjaarsgaard et al., 1995). Experimental studies have shown that the crystallization of wollastonite play an important role in the magmatic evolution of the alkali-rich magmatic systems from foiditic to phonolitic compositions (Kjarsgaard, 1998; Kjaarsgaard et al., 1995; Petibon et al., 1998; Weidendorfer et al., 2017). Although rare in igneous systems, wollastonite is eventually common in silica-undersaturated and carbonatite systems, and is likely to play a role in magma differentiation; the knowledge of trace element partitioning between wollastonite and silicate melts is therefore required if we are to better understand and model magma evolution.

One of the main structural differences between wollastonite and clinopyroxene (diopside) is the ratio between tetrahedral $(\mathrm{T})$ and octahedral $(\mathrm{O})$ sites: T:O ratios are 3:2 for wollastonite and 1:1 for diopside (Thompson et al., 2016). In wollastonite, trace element cations of various charges $(1+$ to $5+)$ and ionic radii are substituted into the three octahedral $\mathrm{Ca}$ sites of similar ionic size (on average $0.99 \AA$ ), compared to the two Ca sites of different ionic sizes in clinopyroxene (Ohashi and Finger, 1978; Thompson et al., 2016). Element partitioning can be modelled by the lattice strain model (LSM), defined by the 'strain-free' partition coefficient $D_{0}$, site elasticity (apparent Young's Modulus) $E$, and site radius $r_{0}$ (e.g., Wood and Blundy, 1997). Trace element partitioning of $1+$ to $4+$ cations between wollastonite and melt has only been established at mantle conditions $\left(3 \mathrm{GPa}, 1420^{\circ} \mathrm{C}\right)$ for silicate-carbonate melt (Law et al., 2000). Law et al. (2000) highlighted relatively high $D_{0}$ for $2+$ and $3+$ cations and a strong dependence between ionic charge and $r_{0}$. They suggested that the relatively lower temperature conditions associated with carbonate-rich silicate melts (e.g., at Oldoinyo Lengai) could promote higher partition coefficients. In the present study, we provide new partition coefficients and associated LSM parameters for wollastonite and alkali-rich foiditic melts. Partition coefficients $(D)$ between wollastonite and liquid will eventually be choice tools to study magma differentiation processes in alkaline-rich magmatic systems at crustal conditions. 
Method and Samples

Samples and Petrography

The cumulative ijolite xenolith 10TL01 studied herein was collected in 2010 on the rim of the northern crater of Oldoinyo Lengai, and is one of the last products erupted during the 2007-2008 eruptive episode (Mollex et al., 2018). The cumulative ijolite sample contains clinopyroxene (30 vol.\%, 100-1000 $\mu \mathrm{m}, \mathrm{Wo}_{48-44} \mathrm{En}_{38-27} \mathrm{Fs}_{14-29}, \mathrm{Ae}_{6-21}$ ), garnet (15 vol.\%, 100$800 \mu \mathrm{m}$, Ti-andradite), apatite ( $8 \mathrm{vol} . \%, 100-1000 \mu \mathrm{m})$ phenocrysts, interstitial nepheline (45 vol.\%) with minor pyrrhotites, titanomagnetite, wollastonite, and interstitial glass. Clinopyroxene, garnet and nepheline crystals host silicate melt inclusions similar to those described by de Moor et al. (2013) and Mitchell and Dawson (2012). Minor Apatite and wollastonite microcrysts $(10-100 \mu \mathrm{m})$ are associated with interstitial melt pockets (2 vol.\%, now quenched to glass); those minerals crystallized late relative to clinopyroxene. Crystal textures and euhedral shapes suggest that wollastonite and apatite are in equilibrium with the interstitial quenched glass that will thus be used hereafter to estimate the partition coefficients (Fig. 1a)(BSE image of the ijolite sample in the supplementary material). The 2007-2008 OL subplinian eruption was triggered by the recharge of the crustal reservoir $\left(\sim 13 \mathrm{~km}, \leq 1000^{\circ} \mathrm{C}\right.$; Albaric et al., 2010, de Moor et al., 2013), and the studied samples therefore document midcrustal witnesses.

Analytical method

Petrographic observations were conducted using back-scattered electron microscopy. Major element concentrations in wollastonite and glass were determined using a CAMECA SX-100 electron microprobe at the SCMEM of Lorraine University (France). Analyses were performed using a $15 \mathrm{kV}$ accelerating voltage. Minerals were analysed using a focused $12 \mathrm{nA}$ beam, and interstitial glass measurements were performed using a spot size of $10 \mu \mathrm{m}$ and a current of $6 \mathrm{nA}$ in order to minimize alkali loss and beam damage of the glass.

Trace element concentrations in minerals were determined by laser ablation inductively coupled plasma mass spectrometry (Thermo Element XR) at Laboratoire Magmas et Volcans (Clermont-Ferrand, France). A 27- $\mu$ m-diameter laser beam was used for 
wollastonite and glass, with a laser repetition rate of $3 \mathrm{~Hz}$ and a laser power of $3 \mathrm{~mJ}$ (4.8 $\mathrm{J} \cdot \mathrm{cm}^{-2}$ ). Trace element analyses were calibrated using International NIST Standard Reference Material 610 and 612 glasses (Gagnon et al., 2008). $\mathrm{CaO}$ concentrations previously determined by electron microprobe were used as internal standards for individual wollastonite and glass analyses. Glitter Software (Griffin et al., 2008) was used to process the raw data files containing the signal intensity versus time, allowing precise selection of blanks and signals.

\section{Results}

Wollastonite composition

Wollastonite occurs as euhedral to well-faceted microcrysts $(10-60 \mu \mathrm{m})$ in the interstitial glass (Fig. 1). Wollastonite displays low variability in silica $\left(\mathrm{SiO}_{2}=50.5-51.7\right.$ wt.\%) and $\mathrm{Ca}$ contents $\left(\mathrm{CaO}=45.6-47.2\right.$ wt.\%), variable total $\mathrm{Fe}\left(\mathrm{FeO}^{\mathrm{t}}, 0.7-1.4\right.$ wt.\%), $\mathrm{MnO}(0.3-0.6$ wt.\%), and $\mathrm{MgO}\left(0.1-0.26\right.$ wt.\%) contents, and high $\mathrm{P}_{2} \mathrm{O}_{5}$ content (0.55-0.76 wt.\%) similar to other wollastonite grains reported for Oldoinyo Lengai (Dawson et al., 1992; Dawson, 1998) (Table 1). The rare earth element (REE) contents of wollastonite are characterized by high light REE (LREE) contents (36.7-63.8 ppm La) relative to middle and heavy REEs (MREE and HREE, 7.2-13.6 ppm Dy and 0.6-1.1 ppm Lu, respectively) and a flat pattern between MREEs and HREEs (Fig. 2). Wollastonite displays high Sr contents (1268-2055 ppm), and relatively low $\mathrm{K}$ (5-20.1 ppm), $\mathrm{Ba}(3.2-14.7 \mathrm{ppm})$, and $\mathrm{Rb}$ contents (0.1-0.16 ppm). High field strength element (HFSE) contents are low for both tetravalent (2.8-20 ppm Zr, 0.05$0.26 \mathrm{ppm} \mathrm{Th}$ ) and pentavalent cations (0.06-0.18 ppm Nb, 0.18-0.5 ppm Mo) (Table 2), and display a strong negative $\mathrm{Zr}-\mathrm{Hf}$ anomaly relative to $\mathrm{Nd}$ and $\mathrm{Sm}$. Other transition metals occur in various concentrations: $\mathrm{Ni}$ varies from 0.9 to $2.1 \mathrm{ppm}$, Co from 0.36 to $2.5 \mathrm{ppm}$, Zn from 6.1 to $39.3 \mathrm{ppm}, \mathrm{Cr}$ from 1.8 to $6.8 \mathrm{ppm}, \mathrm{Sc}$ from 0.17 to $0.43 \mathrm{ppm}$, and Y from 47 to $86 \mathrm{ppm}$.

Interstitial glass composition

Interstitial glasses are silica-poor $\left(\mathrm{SiO}_{2}=40.9-44.8\right.$ wt.\%), and have high $\mathrm{FeO}^{\mathrm{t}}(11.9-$ 17 wt.\%), alkali $\left(\mathrm{Na}_{2} \mathrm{O}+\mathrm{K}_{2} \mathrm{O}=18.4-19.8\right.$ wt.\%), and volatile contents (0.5-1 wt.\% F, $1.2-$ 2.5 wt.\% $\mathrm{SO}_{3}$, and $0.4-0.6$ wt.\% $\left.\mathrm{Cl}\right)$. Glasses have very low $\mathrm{MgO}(1.2-1.6$ wt.\%) and moderate $\mathrm{CaO}\left(6.5-8\right.$ wt.\%) and $\mathrm{Al}_{2} \mathrm{O}_{3}$ contents (5-5.9 wt.\%) (Table 1). They have a very high peralkaline index (4.5-5.6), and display foiditic compositions. Similar interstitial melts have been previously analysed and described as alkali-rich nephelinites (de Moor et al., 2013; 
Mitchell and Dawson 2012) (Fig. 1b). Interstitial glasses exhibit high LREE concentrations (e.g., 255-313 ppm La) and concentrations decrease from LREEs to HREEs (0.8-1.1 ppm Ho, 0.3-0.36 ppm Lu, La/Lu = 800-960). Very high large ion lithophile element (LILE) contents are observed, in particular for Ba (2214-2920 ppm) and $\mathrm{Sr}$ (2671-3484 ppm) (Table 2). Glasses have relatively low concentrations of the transitional metals $\mathrm{Sc}, \mathrm{Cr}$, and $\mathrm{Ni}(<4$ ppm) and high Zn and V contents (320-452 ppm Zn, 149-207 ppm V) (Table 2). Glasses are also characterized by a fractionation between $\mathrm{Nb}$ and $\mathrm{Ta}(374-549 \mathrm{ppm} \mathrm{Nb}, \mathrm{Nb} / \mathrm{Ta}=69-78)$, high $\mathrm{Zr}$ content (722-1034 ppm), and low pentavalent cation contents (2.6-7.1 ppm Mo, 0.81-1.22 ppm Sb) (Table 2).

\section{Discussion}

Wollastonite-melt partition coefficients

We have determined trace element partition coefficients $(D)$ between the interstitial glass and coexisting wollastonite (Table 2), in which trace elements are incorporated into the $\mathrm{Ca}^{2+}$ site (Fig. 3). LILEs display very low partition coefficients $\left(D_{\mathrm{Rb}}=0.004 \pm 0.002, D_{\mathrm{Na}}=\right.$ $\left.0.01 \pm 0.008, D_{\mathrm{Ba}}=0.003 \pm 0.001\right)$, except for $\mathrm{Sr}^{2+}\left(D_{\mathrm{Sr}}=0.5 \pm 0.1\right)$. Bivalent transition metals have various $D$ values increasing from $\mathrm{Zn}^{2+}(0.03 \pm 0.006)$ to $\mathrm{Co}^{2+}$ and $\mathrm{Mg}^{2+}(0.11 \pm$ 0.03 and $0.12 \pm 0.02$, respectively) to $\mathrm{Mn}^{2+}(1.01 \pm 0.07)$. LREEs behave incompatibly $\left(D_{\mathrm{La}}=\right.$ $0.18 \pm 0.04$ to $\left.D_{\mathrm{Sm}}=0.98 \pm 0.15\right)$, whereas HREEs $\left(D_{\mathrm{Eu}}=1.19 \pm 0.19\right.$ to $\left.D_{\mathrm{Lu}}=2.67 \pm 0.5\right), \mathrm{Y}$, and $\mathrm{Cr}$ are the only trace elements that behave compatibly with wollastonite (Fig. 3). REE partition coefficients display an important range of values from LREE to HREE and are positively correlated between each others (e.g., $D_{\mathrm{La}}=0.19 \pm 0.03 ; D_{\mathrm{Lu}}=2.8 \pm 0.4$ ). HREE, Y and $\mathrm{Cr}$ are the only trace elements compatible with wollastonite. HFSE partition coefficients are very low for tetravalent (e.g., $D_{\mathrm{Zr}}=0.011 \pm 0.007, D_{\mathrm{Th}}=0.005 \pm 0.002$ ) and pentavalent cations $\left(D_{\mathrm{Nb}}=0.002 \pm 0.001, D_{\mathrm{Ta}}=0.006 \pm 0.002\right)$.

Lattice strain models

Wollastonite-melt partition coefficients $\left(D_{i}\right)$ for chemical elements $i$ of a given valence are correlated to ionic radii and display parabolic distributions, as observed for other silicate minerals (e.g., Adam and Green, 2006; Dalou et al., 2018; Wood and Blundy, 1997). $D_{i}$ can be quantified using the classical LSM equation defined by Blundy and Wood (1994) as: 


$$
D_{i}=D_{0} \exp \left[\frac{-4 \pi E N\left[\frac{r_{0}}{2}\left(r_{i}-r_{0}\right)^{2}+\frac{1}{3}\left(r_{i}-r_{0}\right)^{3}\right]}{R T}\right]
$$

where $D_{i}$ is a function of cation radius ( $r_{i}$ in $\AA$ ), the ideal radius of the crystallographic Ca site occupied by the cations $\left(r_{0}\right)$, the partition coefficient of the ideal cation $\left(D_{0}\right)$ with radius $r_{0}$, elastic constant $E$ (Young's modulus), Avogadro's constant $N$, the universal gas constant $R$, and temperature $T$ (in Kelvin). The best-fit LSM parameters have been extracted using the DOUBLE FIT software (Dalou et al., 2018).

Partition coefficients for several isovalent cations are necessary to suitably constrain the LSM parameters. In this study, 2+ and 3+ partitioning parabolas are well defined, whereas $1+, 4+$, and $5+$ partitioning parabolas are less so due to the sparsity of $D$ values for those valences (Fig. 4).

Monovalent $\mathrm{Rb}$ and $\mathrm{K}$ cations in wollastonite display very low contents that are near the detection limit (Fig. 3). Law et al. (2000) estimated the LSM parameters of wollastonite-melt partitioning in silicate-carbonate melt at mantle conditions $\left(3 \mathrm{GPa}, 1420{ }^{\circ} \mathrm{C}\right)$ for monovalent cations to be ${D_{0}}^{1+}=0.158, E^{1+}=51 \mathrm{GPa}$, and $r_{0}{ }^{1+}=1.17 \AA$. In Oldoinyo Lengai wollastonite, our values for $D_{0}{ }^{1+}(<0.01)$ and $r_{0}{ }^{1+}(\sim 1.15 \pm 0.01 \AA)$ are smaller, whereas $E^{1+}$ is slightly higher (68 $\pm 8 \mathrm{GPa})$ (Fig. 4b). We note that monovalent partition coefficients increase with increasing ionic radius $\left(D_{\mathrm{Na}}>D_{\mathrm{K}}>D_{\mathrm{Rb}}\right)$.

We applied the bivalent cation distribution model to the $\mathrm{Ba}, \mathrm{Sr}, \mathrm{Mg}, \mathrm{Co}$, and $\mathrm{Mn}$ partition coefficients. The best-fit model parameters are $D_{0}{ }^{2+}=2.38, E^{2+}=116.2 \mathrm{GPa}$, and $r_{0}{ }^{2+}=1.003 \AA$. Because $\mathrm{Ca}$ (with $\mathrm{Si}$ ) is the main constituent of wollastonite and is not dependent on melt composition or intensive parameters, $\mathrm{Ca}^{2+}$ was not used in the bivalent LSM. $\mathrm{Zn}^{2+}, \mathrm{Fe}^{2+}$, and $\mathrm{Ni}^{2+}$ deviate from the parabola (Fig. 4a). $D_{\mathrm{Ni}}$ is slightly higher than predicted by the LSM; the unusual preference of $\mathrm{Ni}$ for octahedral sites rather than lowcoordination environments in the melt has been described in previous studies (e.g., George and Stebbins, 1998; Purton et al., 2000) and probably accounts for this deviation. Oppositely, $D_{\mathrm{Zn}}$ is lower than expected, probably due to the preference of $\mathrm{Zn}$ for tetrahedral over octahedral sites (Purton et al., 2000). The iron partition coefficient is not correlated with the other bivalent cations (Fig. 4a). This may be attributed to the presence of $\mathrm{Fe}^{3+}$, as wollastonite can incorporate $\mathrm{Fe}^{3+}$ in tetrahedral sites (e.g. Thompson et al., 2016). The presence of $\mathrm{Fe}^{3+}$ in the melt is expected, as the OL samples commonly contains ferric minerals like andradite and 
219 clinopyroxene (Kjarsgaard, 1998; Klaudius and Keller 2006). $\mathrm{Fe}^{3+}$ and $\mathrm{Fe}^{2+}$ in wollastonite are likely distributed between $\mathrm{Si}^{4+}$ and $\mathrm{Ca}^{2+}$ sites, respectively.

The trivalent parabola is well predicted by the LSM and is mainly constrained by the REEs (Fig. 4b). $D_{0}{ }^{3+}$ and $r_{0}{ }^{3+}$ values are close to those of lutetium $\left(D_{\mathrm{Lu}}=2-3.6 ; r_{\mathrm{Lu}}=0.861\right.$ $\AA$ ). Among the REEs, Lu displays the closest partitioning value to that of Ca (Fig. 4b). Other trivalent cations considered herein are $\mathrm{Cr}, \mathrm{Sc}, \mathrm{Al}$, and $\mathrm{V} . D_{\mathrm{Cr}}$ is higher than predicted by the LSM, possibly due to the presence of $\mathrm{Cr}^{2+}$ and $\mathrm{Cr}^{3+}$ in wollastonite. Similarly, vanadium likely has two oxidation states in our sample (i.e., 3+ and 4+) (Adam and Green, 2006).

Using the partition coefficients determined for $\mathrm{Zr}$, Hf, Th, and $\mathrm{U}$, we obtained the best-fit tetravalent LSM parameters $D_{0}{ }^{4+}=0.011, E^{4+}=51 \mathrm{GPa}$, and $r_{0}{ }^{4+}=0.72 \AA$ (Fig. 5). For pentavalent cations, although Mo and Sb exist with different valence states, we assumed that they behave as $\mathrm{Nb}$ and $\mathrm{Ta}$ and mostly occur as pentavalent cations in our sample (Adam and Green, 2006). Our best-fit parameters for pentavalent cations are $D_{0}{ }^{5+}=0.092, E^{5+}=7106$ $\mathrm{GPa}$, and $r_{0}{ }^{5+}=0.598 \AA$.

Our LSM parameters display a strong correlation with valence. The ideal cation radius $r_{0}$ decreases significantly with cation charge from $r_{0}{ }^{1+}=1.2 \AA$ to $\mathrm{r}_{0}{ }^{5+}=0.6 \AA$ (Fig. 5). The ideal partition coefficient $D_{0}$ is dependent on the charge of the cations: $D_{0}$ values are the greatest for $2+$ and $3+$ cations $\left(D_{0}>1\right)$, whereas those for $4+$ and $1+$ cations are 200-300 times smaller. In general, $r_{0}$ and $D_{0}$ are greater for low $P-T$ alkali melts than those obtained for silicate-carbonate melts at mantle conditions (Law et al., 2000).

Trace element partitioning and implications for wollastonite-bearing igneous rocks

The only previous study providing partition coefficients for wollastonite focused on Ca-rich melt at $1420{ }^{\circ} \mathrm{C}$ and $3 \mathrm{GPa}$ (Law et al., 2000), but these experimental conditions and melt composition are not directly relevant to crustal alkaline magmatic systems (Dawson, 1998; Dawson et al., 1996; Weisenberger et al., 2014). We nevertheless compare our partition coefficients to those of Law et al. (2000) to characterize the impact of wollastonite crystallization on trace element partitioning during magmatic differentiation. Compared to Carich melt at $3 \mathrm{GPa}$, our monovalent and tetravalent partition coefficients are 10 times lower and 10 to 100 times higher, respectively (Fig. 3). As bivalent and trivalent cations have ionic potentials near that of $\mathrm{Ca}^{2+}$, they have higher partition coefficients than $1+, 4+$, and $5+$ cations 
(Fig. 6). REE partition coefficients are 6-7 times higher at the crustal conditions studied herein, and, notably, HREEs behave compatibly. The difference in REE partitioning between the two studies is likely related to the incorporation of minor elements in the Ca site. For example, $\mathrm{Al}^{\mathrm{iv}}$ or $\mathrm{Na}$ contents in clinopyroxene strongly impact REE partitioning (Bennett et al., 2004; Blundy et al., 1998; Hill et al., 2000; Wood and Trigila, 2001). Wollastonite could therefore be affected by a comparable process in the presence of other minor elements such as Fe (Matsueda, 1974; Shimazaki and Yamanaka, 1973), Mn (Brown et al., 1980), or Mg (Jung et al., 2005). Indeed, Oldoinyo Lengai wollastonites are characterized by higher $\mathrm{FeO}^{\mathrm{t}}$ content $(1 \pm 0.2$ wt. $\%)$ and similar $\mathrm{MnO}$ and $\mathrm{MgO}$ contents $(0.4 \pm 0.1$ and $0.2 \pm 0.05$ wt. $\%$, respectively) compared to those of Law et al. (2000; $\left.\sim 0.1 \mathrm{wt}^{2} \mathrm{FeO}^{\mathrm{t}}\right)$. The variability of the partition coefficients may result from the different melt composition between an alkali-rich foiditic silicate melt (43.3 $\mathrm{wt} \% \mathrm{SiO}_{2}, 7.3 \mathrm{wt} \% \mathrm{CaO}, \mathrm{NBO} / \mathrm{T}=1.35$, Table 1) and a silicatecarbonate melt (37.2 wt $\% \mathrm{SiO}_{2}, 47.3 \mathrm{wt} \% \mathrm{CaO}, \mathrm{NBO} / \mathrm{T}=2$, Law et al. 2000). The effect of melt structure (e.g. NBO/T) and composition on trace element partitioning has been identified in previous studies and should not be neglected (Schmidt et al. 2006, Michely et al. 2017, Mollo et al. 2016). According to those authors, an increasing in NBO/T value would imply an important decrease of the partition coefficients down to one order of magnitude (when NBO/T rises from 0.2 to 2). NBO/T differs by less than a factor 2 between the present study and the one of Law et al. (2000), and therefore cannot explain the diversity of the partition coefficients shown in the Fig.3. However, this small melt structure variation may account for the slight modification of partition coefficients for HREE that imply a behaviour modification from moderately incompatible to compatible. One of main difference between the melt compositions is the $\mathrm{CaO}$ content ( 7 to $47 \mathrm{wt} \% \mathrm{CaO}$ ) that could affect the partition coefficients. Di Stefano et al. (2019), proposed that the addition of $\mathrm{CaCO}_{3}(+20 \%)$ triggers a decrease of the $D_{\mathrm{R} 3+}^{\text {olivine-melt }}$ (e.g. $-40 \%$ on $\mathrm{D}_{\mathrm{Sc}}$ ), consistent with the trend that has been observed herein for $D_{\mathrm{HREE}}^{\mathrm{Wo}-m e l t}$ (Fig. 3). Further investigations and experimental studies are necessary to examine the effect of minor-element incorporation ( $\mathrm{Mn}, \mathrm{Mg}$ ), melt composition (e.g. Ca and Alkali contents) and intensive parameter (P, T) on REE partitioning in wollastonites.

Wollastonite is the pyroxenoids calcic end-member, and is likely to provide us with key information on the partitioning of trace elements in the Ca site of silicate phases. Also due to the connection between tetrahedral chains and octahedrally coordinated cations, wollastonite crystal structure is similar to the one of pyroxene, and partitioning of trace 
elements is likely close for the two mineral species. Trace element partition coefficients between wollastonite and alkali-rich silicate melt $\left(D_{i}^{\mathrm{Wo}}\right)$, and between clinopyroxene and phonolitic melt $\left(D_{i}^{\mathrm{Cpx}}\right)$ are relatively close for LREE although $D_{\mathrm{LREE}}^{\mathrm{Wo}}$-melt is slightly higher that $D_{\text {HREE }}^{\text {Cpx-melt }} D_{\text {LREE }}$ (Fig. 3). The difference increase for HREE with $D_{\text {HREE }}^{\text {Wo-melt }}$ almost 10 times higher than $D_{\mathrm{HREE}}^{\mathrm{Cpx}-\text { melt }}$ (Fig. 3). More importantly, the behavior of LREE and HREE are different in Cpx and wollastonite; all REE are indeed incompatible in Cpx when HREE are compatible in wollastonite. This implies that both $\mathrm{Cpx}$ and wollastonite fractionation would result in LREE enrichment in the melt, and that Cpx fractionation leads to an enrichment in HREE when wollastonite fractionation drives the melt HREE content to lower values. This difference of partitioning behavior between $\mathrm{Cpx}$ and wollastonite therefore results in different LREE/HREE fractionations while crystallizing $\mathrm{Cpx}$ and wollastonite. This difference of behavior between LREE and HREE, and more specifically the compatible character of HREE in wollastonite may become a key information for economic geology, and prospective issues as REE deposits are usually associated with igneous endmembers related to protracted differentiation of alkaline melts (e.g., Verplanck et al., 2014).

$\mathrm{Zr}$ and $\mathrm{Hf}$ partition coefficients in wollastonite are very low relative to those in clinopyroxene. In clinopyroxene, HFSEs substitute for $\mathrm{Mg}$ or Fe in the M1 site, which has a very similar size to the $\mathrm{Zr}$ and $\mathrm{Hf}$ ionic radii (Shannon, 1976), whereas the $\mathrm{Ca}$ site in wollastonite is too large to efficiently accommodate HFSEs. Monovalent cation (e.g., Rb) and HFSE ( $\mathrm{Zr}, \mathrm{Nb}$ ) partition coefficients in orthopyroxene (Opx) are in the same range as those determined herein for wollastonite, whereas $D_{\mathrm{REE}}^{\mathrm{Opx}}$ and $D_{\mathrm{Sr}}^{\mathrm{Opx}}$ are 100 times lower than in wollastonite (Adam and Green, 2006; van Kan Parker et al., 2010). $D_{\text {REE }}$ of the pyroxenes are lower than $D_{\mathrm{REE}}^{\mathrm{Wo}-\text { melt }}$ because REE are incorporated into the Ca site (e.g. Law et al. 2000; Wood and Blundy, 1997) and wollastonite are richer in Ca sites within their crystal lattices.

Carbonatites have been proposed to result from extreme differentiation of alkali-rich and silica-undersaturated melts (Jones et al., 2013; Weidendorfer et al., 2017). Wollastonite is present in alkaline rocks associated with carbonatites (e.g., Dawson, 1998; Dawson et al., 1996; Eckermann, 1974; Weisenberger et al., 2014), and related to the evolved terms of the liquid line of descent (e.g. Kjarsgaard, 1998; Kjaarsgaard et al., 1995). The crystallization of wollastonite would thus strongly fractionate LREEs $\left(D_{\text {LREE }}<1\right)$ from HREEs $\left(D_{\text {HREE }}>1\right)$. Wollastonite crystallization in alkaline-carbonatitic volcanic systems may eventually strongly affect trace element fractionation during the magmatic evolution, leaving the residual melt 
depleted in HREEs and enriched in LREEs. It finally implies that on a REE deposit prospects perspective in the alkaline-carbonatitic systems, wollastonite crystallization should be taken into consideration if we are to track new deposits or to elaborate prospection strategies.

Conclusion

We have determined trace element partition coefficients between wollastonite and silicate melts at crustal conditions relevant to alkaline-rich and silica-undersaturated magmatic systems. Most of the elements analysed behave incompatibly in wollastonite, including monovalent $(\mathrm{Rb})$, bivalent $(\mathrm{Ba})$, tetravalent, and pentavalent cations. On the basis of the lattice strain model, we identify that trace elements are incorporated into the $\mathrm{Ca}$ site with an ideal radius $\left(r_{0}\right)$ that decreases significantly with cation charge from $r_{0}{ }^{1+}=1.2 \AA$ to $r_{0}{ }^{5+}=0.6 \AA$, and that $D_{0}$ for $2+$ and $3+$ cations are 200 times higher than those for $4+$ and $1+$ cations. HFSE partition coefficients are particularly low $(<0.01)$ for tetravalent cations, and wollastonite crystallization could therefore contribute to HFSE enrichment of the melt during differentiation. $\mathrm{Mn}$ is slightly compatible $(D=1.01)$, and middle to heavy REEs show increasing compatibility from $D_{\mathrm{Eu}}=1.2$ to $D_{\mathrm{Lu}}=2.7$. The crystallization of wollastonite therefore potentially plays a key role in fractionating LREEs and HREEs in silicaundersaturated melt-carbonatite suites.

\section{Acknowledgments}

We thank the Tanzania commission for science and technology (COSTECH) for the field permits. The authors acknowledge the help of Robert Dennen for English editing. This research was financially supported by the French National Research Agency through the national program "Investissements d'avenir" with the reference ANR-10-LABX-21 01/LABEX RESSOURCES21, and through the project GECO-REE (ANR-16-CE01-0003-01; P.I.: Lydéric France). This study has also been supported by the Région Lorraine, and Région Grand-Est, and PNP and CESSUR programs from INSU-CNRS (grants to Lydéric France). This is CRPG contribution $n^{\circ} \mathrm{XX}$, and GECO-REE contribution $\mathrm{n}^{\circ} \mathrm{XXX}$. 
Figure captions

Fig. 1. (a) Back-scattered electron image of ijolite xenolith 10TL01 from Oldoinyo Lengai volcano. Abbreviations: Wo, wollastonite; Cpx, clinopyroxene; Ap, apatite; and Nph, nepheline. Coexisting interstitial glass is shown in green. (b) Alkali vs silica content of interstitial melts.

Fig. 2. Trace element variation diagrams of Oldoinyo Lengai wollastonite and associated melt. Trace element variations of wollastonite and melt from an experimental study (Law et al., 2000) and wollastonite in a carbonaceous chondrite (Komorowski et al., 2007) are presented for comparison.

Fig. 3. Trace element partition coefficients $\left(D^{\mathrm{mineral} / \mathrm{melt}}\right)$ obtained for Oldoinyo Lengai wollastonite/alkali-rich foiditic silicate melt $(\mathrm{NBO} / \mathrm{T}=1.35)$ in this study are shown by the thick black line and open circles; $1 \sigma$ errors are shown in gray. Data from previous studies are experimental wollastonite/silicate-carbonate melt $\left(37.2 \mathrm{wt} \% \mathrm{SiO}_{2}\right.$ and $47.3 \mathrm{wt} \% \mathrm{CaO}$, $\mathrm{NBO} / \mathrm{T}=2$, Law et al., 2000), clinopyroxene/phonolitic melt (NBO/T=0.4, Mollo et al. 2016), and orthopyroxene/silicate melt (CMAS composition, NBO/T=0.79, van Kan Parker et al., 2010). Elements are ranked according to cation charge and increasing ionic radius.

Fig. 4. Wollastonite/melt partition coefficients $\left(D^{\text {wollastonite/melt }}\right)$ vs. ionic radius for (a) bivalent cations and (b) $1+, 2+, 3+$, and $4+$ cations. The best-fit lattice strain model parameters were determined using the DOUBLE FIT program (Dalou et al., 2018). Dashed curves show the best-fit lattice strain model for $2+$ cations without $\mathrm{Ca}$ (major element in wollastonite).

Fig. 5. (a) Partition coefficients of the ideal cation $\left(D_{0}\right)$ and (b) ideal site radii $r_{0}$ for cations of different valence $(1+, 2+, 3+, 4+$, and $5+)$.

379 Table

Fig. 6. Partition coefficient vs ionic potential $(Z / r)$ for cations of different valence. Only bivalent and trivalent cations ( $\mathrm{Ca}, \mathrm{Mn}, \mathrm{HREEs}, \mathrm{Y}$, and $\mathrm{Cr}$ ) reach compatibility in wollastonite.

Table 1: Major element composition of wollastonites and interstitial melts (wt\%)

\begin{tabular}{lll} 
Wollastonite & \multicolumn{2}{c}{ Melt } \\
$\mathrm{n}=23$ & $1 \sigma \quad \mathrm{n}=16^{1 \sigma}$
\end{tabular}




\begin{tabular}{ccccc}
$\mathrm{SiO}_{2}$ & 51.08 & 0.55 & 43.27 & 0.50 \\
$\mathrm{TiO}_{2}$ & 0.04 & 0.03 & 0.61 & 0.09 \\
$\mathrm{Al}_{2} \mathrm{O}_{3}$ & 0.00 & 0.03 & 5.54 & 0.44 \\
$\mathrm{FeO}_{\mathrm{t}}$ & 0.98 & 0.16 & 13.62 & 0.98 \\
$\mathrm{MnO}$ & 0.37 & 0.14 & 0.61 & 0.32 \\
$\mathrm{MgO}$ & 0.18 & 0.05 & 1.39 & 0.13 \\
$\mathrm{CaO}$ & 46.38 & 1.1 & 7.33 & 0.35 \\
$\mathrm{Na} 2$ & 0.12 & 0.08 & 13.61 & 0.77 \\
$\mathrm{~K}_{2} \mathrm{O}$ & 0.02 & 0.04 & 5.72 & 0.22 \\
$\mathrm{P}_{2} \mathrm{O}_{5}$ & 0.68 & 0.09 & 1.09 & 0.11 \\
$\mathrm{~F}$ & - & - & 0.70 & 0.21 \\
$\mathrm{SO}_{3}$ & - & - & 1.63 & 0.22 \\
$\mathrm{Cl}$ & - & - & 0.49 & 0.09 \\
$\mathrm{Total}$ & 99.87 & & 95.6 & \\
\hline
\end{tabular}

Table 2: Trace element concentrations (ppm) in wollastonite and interstitial alkali-rich silicate melt of Oldoinyo Lengai ijolite xenolith 10TL01 and their wollastonite/melt partition coefficients $(D)$.

\begin{tabular}{ccccccc}
\hline Element & Wollastonite & $1 \sigma$ & Melt & $1 \sigma$ & $\mathrm{D}$ & $1 \sigma$ \\
\hline $\mathrm{Li}$ & 4.37 & 0.31 & 51.7 & 2.23 & 0.085 & 0.005 \\
$\mathrm{Be}$ & 0.13 & 0.04 & 19.2 & 1.98 & 0.007 & 0.001 \\
$\mathrm{~B}$ & 4.44 & 0.48 & 28.6 & 1.92 & 0.16 & 0.01 \\
$\mathrm{Na}$ & 890 & 296 & 101041 & 400 & 0.009 & 0.002 \\
$\mathrm{Mg}$ & 1086 & 100 & 8383 & 301 & 0.13 & 0.008 \\
$\mathrm{Al}$ & 50.9 & 0.94 & 18746 & 716 & 0.003 & $8 \mathrm{E}-05$ \\
$\mathrm{~K}$ & 11.5 & 0.91 & 30499 & 1298 & 0.000 & $6 \mathrm{E}-05$ \\
$\mathrm{Sc}$ & 0.30 & 0.08 & 1.69 & 0.08 & 0.18 & 0.03 \\
$\mathrm{Ti}$ & 355 & 25.3 & 5967 & 521 & 0.06 & 0.005 \\
$\mathrm{~V}$ & 1.53 & 0.07 & 192 & 6.12 & 0.008 & 0.0003 \\
$\mathrm{Cr}$ & 5.83 & 1.41 & 2.49 & 0.69 & 2.35 & 0.8 \\
$\mathrm{Fe}$ & 7616 & 1165 & 105968 & 1200 & 0.07 & 0.006 \\
$\mathrm{Mn}$ & 2604 & 143 & 2344 & 120 & 1.11 & 0.06 \\
$\mathrm{Co}$ & 1.47 & 0.12 & 12.2 & 0.44 & 0.12 & 0.007 \\
$\mathrm{Ni}$ & 1.45 & 0.36 & 2.21 & 0.24 & 0.66 & 0.12 \\
$\mathrm{Zn}$ & 8.9 & 0.92 & 400 & 21.8 & 0.02 & 0.002 \\
$\mathrm{Rb}$ & 0.11 & 0.03 & 84.9 & 3.46 & 0.0012 & 0.0003 \\
$\mathrm{Sr}$ & 1570 & 40.5 & 3242 & 108 & 0.48 & 0.01 \\
$\mathrm{Y}$ & 65.9 & 2.06 & 32.0 & 1.15 & 2.06 & 0.07 \\
$\mathrm{Zr}$ & 10.2 & 0.11 & 930 & 31.7 & 0.01 & 0.0003 \\
$\mathrm{Nb}$ & 0.38 & 0.008 & 498 & 17.1 & 0.001 & $4 \mathrm{E}-05$ \\
$\mathrm{Mo}$ & 0.37 & 0.04 & 5.05 & 0.16 & 0.07 & 0.005 \\
$\mathrm{Sb}$ & 0.07 & 0.03 & 1.05 & 0.05 & 0.07 & 0.02 \\
& & & & & &
\end{tabular}




\begin{tabular}{ccccccc}
$\mathrm{Ba}$ & 4.98 & 0.16 & 2643 & 91.5 & 0.002 & $8 \mathrm{E}-05$ \\
$\mathrm{La}$ & 52.7 & 1.48 & 276 & 9.65 & 0.19 & 0.01 \\
$\mathrm{Ce}$ & 137 & 3.99 & 426 & 15.0 & 0.32 & 0.01 \\
$\mathrm{Pr}$ & 17.8 & 0.53 & 36.7 & 1.27 & 0.48 & 0.02 \\
$\mathrm{Nd}$ & 73.5 & 2.20 & 114 & 3.96 & 0.64 & 0.02 \\
$\mathrm{Sm}$ & 14.3 & 0.49 & 14.65 & 0.55 & 0.98 & 0.04 \\
$\mathrm{Eu}$ & 4.70 & 0.15 & 3.82 & 0.14 & 1.23 & 0.04 \\
$\mathrm{Gd}$ & 13.5 & 0.43 & 9.20 & 0.35 & 1.47 & 0.05 \\
$\mathrm{~Tb}$ & 1.88 & 0.06 & 1.10 & 0.04 & 1.71 & 0.06 \\
$\mathrm{Dy}$ & 10.7 & 0.33 & 5.52 & 0.22 & 1.93 & 0.07 \\
$\mathrm{Ho}$ & 2.07 & 0.07 & 0.96 & 0.04 & 2.17 & 0.08 \\
$\mathrm{Er}$ & 5.65 & 0.20 & 2.45 & 0.10 & 2.31 & 0.09 \\
$\mathrm{Tm}$ & 0.82 & 0.03 & 0.33 & 0.02 & 2.50 & 0.10 \\
$\mathrm{Yb}$ & 5.79 & 0.20 & 2.26 & 0.10 & 2.56 & 0.10 \\
$\mathrm{Lu}$ & 0.88 & 0.03 & 0.32 & 0.01 & 2.75 & 0.11 \\
$\mathrm{Hf}$ & 0.16 & 0.007 & 10.6 & 0.36 & 0.015 & 0.0006 \\
$\mathrm{Ta}$ & 0.02 & 0.002 & 6.53 & 0.22 & 0.003 & 0.0003 \\
$\mathrm{~Pb}$ & 0.86 & 0.04 & 60.7 & 3.02 & 0.014 & 0.0008 \\
$\mathrm{Th}$ & 0.11 & 0.004 & 33.3 & 1.13 & 0.003 & 0.0001 \\
$\mathrm{U}$ & 0.05 & 0.003 & 14.3 & 0.53 & 0.004 & 0.0002 \\
\hline
\end{tabular}

\section{References}

Albaric, J., Perrot, J., Déverchère, J., Deschamps, A., Le Gall, B., Ferdinand, R. W., Petit, C. Tiberi, C., Sue, C., \& Songo, M. (2010). Contrasted seismogenic and rheological behaviours from shallow and deep earthquake sequences in the North Tanzanian Divergence, East Africa. Journal of African Earth Sciences, 58(5), 799-811.

Adam, J., \& Green, T. (2006). Trace element partitioning between mica-and amphibolebearing garnet lherzolite and hydrous basanitic melt: 1. Experimental results and the investigation of controls on partitioning behaviour. Contributions to Mineralogy and Petrology, 152(1), 1-17.

Bennett, S. L., Blundy, J., \& Elliott, T. (2004). The effect of sodium and titanium on crystalmelt partitioning of trace elements. Geochimica et Cosmochimica Acta, 68(10), 2335-2347.

Blundy, J., \& Wood, B. (1994). Prediction of crystal-melt partition coefficients from elastic moduli. Nature, 372(6505), 452. doi:10.1038/372452a0 
Blundy, J. D., Robinson, J. A. C., \& Wood, B. J. (1998). Heavy REE are compatible in clinopyroxene on the spinel lherzolite solidus. Earth and Planetary Science Letters, 160(3), 493-504.

Braunger, S., Marks, M. A. W., Walter, B. F., Neubauer, R., Reich, R., Wenzel, T., Parsapoor, A., \& Markl, G. (2018). The Petrology of the Kaiserstuhl Volcanic Complex, SW Germany: The Importance of Metasomatized and Oxidized Lithospheric Mantle for Carbonatite Generation. Journal of Petrology, 59(9), 1731-1762.

Brown, P. E., Essene, E. J., \& Peacor, D. R. (1980). Phase relations inferred from field data for Mn pyroxenes and pyroxenoids. Contributions to Mineralogy and Petrology, 74(4), 417425 .

Dawson, J. B. (1998). Peralkaline nephelinite-natrocarbonatite relationships at Oldoinyo Lengai, Tanzania. Journal of Petrology, 39(11-12), 2077-2094.

Dawson, J. B., Smith, J. V., \& Steele, I. M. (1992). 1966 ash eruption of the carbonatite volcano Oldoinyo Lengai: mineralogy of lapilli and mixing of silicate and carbonate magmas. Mineralogical Magazine, 56(382), 1-16.

Dawson, J. B., Smith, J. V., \& Steele, I. M. (1995). Petrology and mineral chemistry of plutonic igneous xenoliths from the carbonatite volcano, Oldoinyo Lengai, Tanzania. Journal of Petrology, 36(3), 797-826.

Dawson, J. B., Pyle, D. M., \& Pinkerton, H. (1996). Evolution of natrocarbonatite from a wollastonite nephelinite parent: evidence from the June, 1993 eruption of Oldoinyo Lengai, Tanzania. The Journal of Geology, 104(1), 41-54.

Dalou, C., Boulon, J., Koga, K. T., Dalou, R., \& Dennen, R. (2018). DOUBLE FIT: Optimization procedure applied to lattice strain model. Computers \& Geosciences, vol 117, 49-56.

de Moor, J. M., Fischer, T. P., King, P. L., Botcharnikov, R. E., Hervig, R. L., Hilton, D. R., Ramirez, C. (2013). Volatile-rich silicate melts from Oldoinyo Lengai volcano (Tanzania): Implications for carbonatite genesis and eruptive behavior. Earth and Planetary Science Letters, 361, 379-390.

Di Stefano, F., Mollo, S., Blundy, J., Scarlato, P., Nazzari, M., \& Bachmann, O. (2019). The effect of $\mathrm{CaO}$ on the partitioning behavior of REE, $\mathrm{Y}$ and $\mathrm{Sc}$ between olivine and melt: Implications for basalt-carbonate interaction processes. Lithos, 326, 327-340.

Eckermann, H. V. (1974). The chemistry and optical properties of some minerals of the Alnö alkaline rocks. Arkiv för Mineralogi och Geologi, 5, 93-210.

Gagnon, J. E., B. J. Fryer, I. M. Samson, and A. E. Williams - Jones (2008), Quantitative analysis of silicate certified reference materials by LA - ICPMS with and without an internal standard, J. Anal. At . Spectrom., 23, 1529-1537, doi:10.1039/b801807n. 
George, A. M., \& Stebbins, J. F. (1998). Structure and dynamics of magnesium in silicate melts: A high-temperature 25Mg NMR study. American Mineralogist, 83(9-10), 1022-1029.

Gold, D.P. (1966) The minerals of the Oka carbonatite and alkaline complex, Oka, Quebec. Pp. 109-25 in Mineralogical Society of India, I.M.A. Volume (P.R.J. Naidu, editor). Mysore University, India.

Griffin, W. L. (2008). GLITTER: data reduction software for laser ablation ICP-MS. Laser Ablation ICP-MS in the Earth Sciences: Current practices and outstanding issues, 308-311.

Hill, E., Wood, B. J., \& Blundy, J. D. (2000). The effect of Ca-Tschermaks component on trace element partitioning between clinopyroxene and silicate melt. Lithos, 53(3), 203-215.

Jones, A. P., Genge, M., \& Carmody, L. (2013). Carbonate melts and carbonatites. Reviews in Mineralogy and Geochemistry, 75(1), 289-322.

Jung, I. H., Decterov, S. A., \& Pelton, A. D. (2005). Critical thermodynamic evaluation and optimization of the $\mathrm{CaO}-\mathrm{MgO}-\mathrm{SiO} 2$ system. Journal of the European Ceramic Society, 25(4), 313-333.

Keller, J., Klaudius, J., Kervyn, M., Ernst, G. G., Mattsson, H. B. (2010). Fundamental changes in the activity of the natrocarbonatite volcano Oldoinyo Lengai, Tanzania. Bulletin of Volcanology, 72(8), 893-912.

Klaudius, J., Keller, J. (2006). Peralkaline silicate lavas at Oldoinyo Lengai, Tanzania. Lithos, 91(1), 173-190.

Kjarsgaard, B. A. (1998). Phase relations of a carbonated high-CaO nephelinite at 0.2 and 0.5 GPa. Journal of Petrology, 39(11-12), 2061-2075.

Kjarsgaard, B. A., Hamilton, D. L., \& Peterson, T. D. (1995). Peralkaline nephelinite/carbonatite liquid immiscibility: comparison of phase compositions in experiments and natural lavas from Oldoinyo Lengai. In Carbonatite Volcanism (pp. 163190). Springer, Berlin, Heidelberg.

Komorowski, C. L., Zinner, E. K., McKeegan, K. D., Hervig, R., \& Buseck, P. R. (2007). The White Angel: A unique wollastonite-bearing, mass-fractionated refractory inclusion from the Leoville CV3 carbonaceous chondrite. Meteoritics \& Planetary Science, 42(7-8), 1159-1182.

Law, K. M., Blundy, J. D., Wood, B. J., \& Ragnarsdottir, K. V. (2000). Trace element partitioning between wollastonite and silicate-carbonate melt. Mineralogical magazine 64(4), 651-661. https://doi.org/10.1180/002646100549670

Masotta, M., Mollo, S., Freda, C., Gaeta, M., \& Moore, G. (2013). Clinopyroxene-liquid thermometers and barometers specific to alkaline differentiated magmas. Contributions to Mineralogy and Petrology, 166(6), 1545-1561. 
Matsueda, H. (1973). Iron-wollastonite from the Sampo mine showing properties distinct from those of wollastonite. Mineralogical Journal, 7(2), 180-201.

Melluso, L., Conticelli, S., D’Antonio, M., Mirco, N. P., \& Saccani, E. (2004). Petrology and mineralogy of wollastonite-and melilite-bearing paralavas from the Central Apennines, Italy. American Mineralogist, 88(8-9), 1287-1299.

Michely, L. T., Leitzke, F. P., Speelmanns, I. M., \& Fonseca, R. O. C. (2017). Competing effects of crystal chemistry and silicate melt composition on trace element behavior in magmatic systems: insights from crystal/silicate melt partitioning of the REE, HFSE, Sn, In, $\mathrm{Ga}, \mathrm{Ba}, \mathrm{Pt}$ and Rh. Contributions to Mineralogy and Petrology, 172(6), 39.

Mitchell, R. H., \& Dawson, J. B. (2012). Carbonate-silicate immiscibility and extremely peralkaline silicate glasses from Nasira cone and recent eruptions at Oldoinyo Lengai Volcano, Tanzania. Lithos, 152, 40-46.

Mollex, G. (2017). Architecture de la plomberie du volcan carbonatitique Oldoinyo Lengai: nouvelles contraintes sur la source, les transferts hydrothermaux, et la différenciation magmatique dans la chambre active (Doctoral dissertation, Université de Lorraine).

Mollex, G., Füri, E., Burnard, P., Zimmermann, L., Chazot, G., Kazimoto, E. O., Marty B., France, L. (2018). Tracing helium isotope compositions from mantle source to fumaroles at Oldoinyo Lengai volcano, Tanzania. Chemical Geology, 418, 66-74. https://doi.org/10.1016/j.chemgeo.2017.08.015

Mollo, S., Forni, F., Bachmann, O., Blundy, J. D., De Astis, G., \& Scarlato, P. (2016). Trace element partitioning between clinopyroxene and trachy-phonolitic melts: A case study from the Campanian Ignimbrite (Campi Flegrei, Italy). Lithos, 252, 160-172. https://doi.org/10.1016/j.lithos.2016.02.024

Ohashi, Y., \& Finger, L. W. (1978). The role of octahedral cations in pyroxenoid crystal chemistry; I, Bustamite, wollastonite, and the pectolite-schizolite-serandite series. American Mineralogist, 63(3-4), 274-288.

Petibon, C. M., Kjarsgaard, B. A., Jenner, G. A., Jackson, S. E. (1998). Phase relationships of a silicate-bearing natrocarbonatite from Oldoinyo Lengai at 20 and $100 \mathrm{MPa}$. Journal of Petrology, 39(11-12), 2137-2151.

Purton, J. A., Blundy, J. D., \& Allan, N. L. (2000). Computer simulation of high-temperature, forsterite-melt partitioning. American Mineralogist, 85(7-8), 1087-1091. https://doi.org/10.2138/am-2000-0726

Ruberti, E., Enrich, G. E., Azzone, R. G., Comin-Chiaramonti, P., De Min, A., \& Gomes, C. B. (2012). The Banhadão Alkaline Complex, Southeastern Brazil: source and evolution of potassic $\mathrm{SiO}_{2}$-undersaturated high-Ca and low-Ca magmatic series. Mineralogy and Petrology, 104(1-2), 63-80. 
Schmidt, M. W., Connolly, J. A. D., Günther, D., \& Bogaerts, M. (2006). Element partitioning: the role of melt structure and composition. Science, 312(5780), 1646-1650.

Shannon, R. D. (1976). Revised effective ionic radii and systematic studies of interatomic distances in halides and chalcogenides. Acta crystallographica section A: crystal physics, diffraction, theoretical and general crystallography, 32(5), 751767.https://doi.org/10.1107/S0567739476001551

Sharygin, V. V., Kamenetsky, V. S., Zaitsev, A. N., \& Kamenetsky, M. B. (2012). Silicatenatrocarbonatite liquid immiscibility in 1917 eruption combeite-wollastonite nephelinite, Oldoinyo Lengai Volcano, Tanzania: Melt inclusion study. Lithos, 152, 23-39.

Shimazaki, H., \& Yamanaka, T. (1973). Iron-wollastonite from skarns and its stability relation in the $\mathrm{CaSiO}_{3}-\mathrm{CaFeSi}_{2} \mathrm{O}_{6}$ join. Geochemical Journal, 7(2), 67-79.

Thompson, R. M., Yang, H., \& Downs, R. T. (2016). Ideal wollastonite and the structural relationship between the pyroxenoids and pyroxenes. American Mineralogist, 101(11), 25442553. https://doi.org/10.2138/am-2016-5683

van Kan Parker, M., Liebscher, A., Frei, D., van Sijl, J., van Westrenen, W., Blundy, J., \& Franz, G. (2010). Experimental and computational study of trace element distribution between orthopyroxene and anhydrous silicate melt: substitution mechanisms and the effect of iron. Contributions to Mineralogy and Petrology, 159(4), 459-473.

Weidendorfer, D., Schmidt, M. W., \& Mattsson, H. B. (2017). A common origin of carbonatite magmas. Geology, 45(6), 507-510.

Weisenberger, T. B., Spürgin, S., \& Lahaye, Y. (2014). Hydrothermal alteration and zeolitization of the Fohberg phonolite, Kaiserstuhl Volcanic Complex, Germany. International Journal of Earth Sciences, 103(8), 2273-2300.

Verplanck, P.L., Van Gosen, B.S., Seal, R.R., McCafferty, A.E. (2014) A Deposit Model for Carbonatiteand Peralkaline Intrusion-Related Rare Earth Element Deposits. Mineral Deposit Models for Resource Assessment 58 p.

Whitney, P. R., \& Olmsted, J. F. (1998). Rare earth element metasomatism in hydrothermal systems: The Willsboro-Lewis wollastonite ores, New York, USA. Geochimica et Cosmochimica Acta, 62(17), 2965-2977.

Wood, B. J., \& Blundy, J. D. (1997). A predictive model for rare earth element partitioning between clinopyroxene and anhydrous silicate melt. Contributions to Mineralogy and Petrology, 129(2-3), 166-181

Wood, B. J., \& Trigila, R. (2001). Experimental determination of aluminous clinopyroxenemelt partition coefficients for potassic liquids, with application to the evolution of the Roman province potassic magmas. Chemical Geology, 172(3), 213-223. 
Woolley, A. R., Williams, C. T., Wall, F., Garcia, D., \& Moute, J. (1995). The Bingo carbonatite-ijolite-nepheline syenite complex, Zaire: geology, petrography, mineralogy and petrochemistry. Journal of African Earth Sciences, 21(3), 329-348.

Zaitsev, A. N., Marks, M. A. W., Wenzel, T., Spratt, J., Sharygin, V. V., Strekopytov, S., \& Markl, G. (2012). Mineralogy, geochemistry and petrology of the phonolitic to nephelinitic Sadiman volcano, Crater Highlands, Tanzania. Lithos, 152, 66-83. 

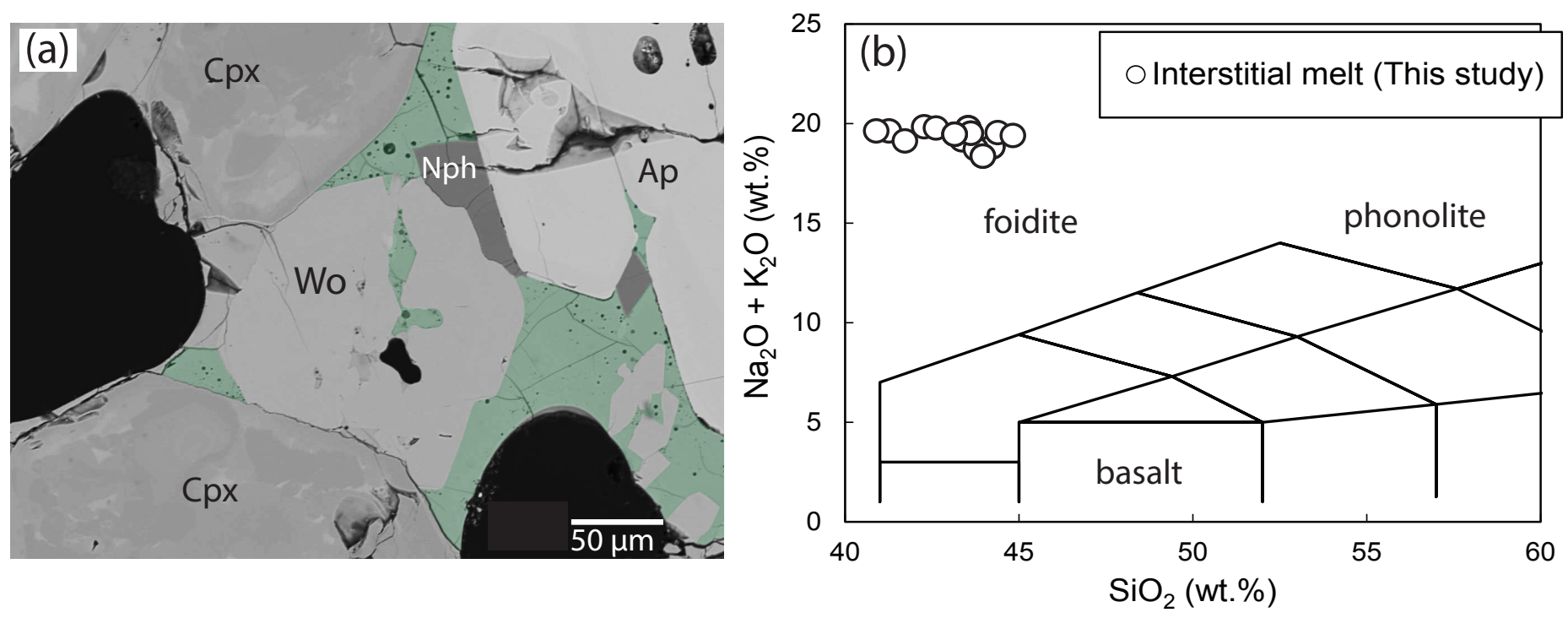


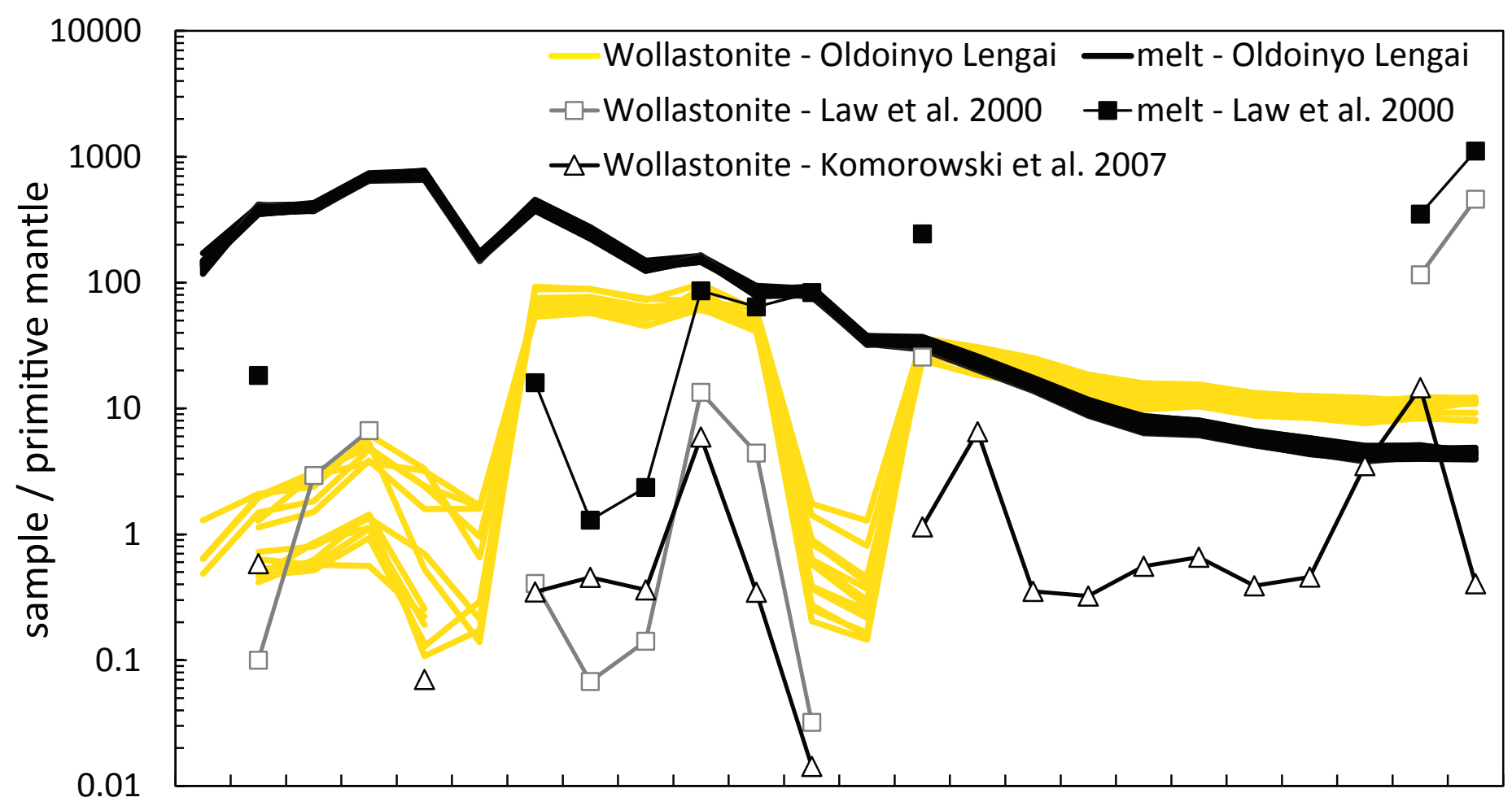

$\mathrm{Rb} \mathrm{Ba}$ Th $\mathrm{U}$ Nb Ta La Ce Pr Sr Nd Zr Hf Sm Eu Gd Tb Dy Y Ho Er Tm Yb Lu 
Figure 3

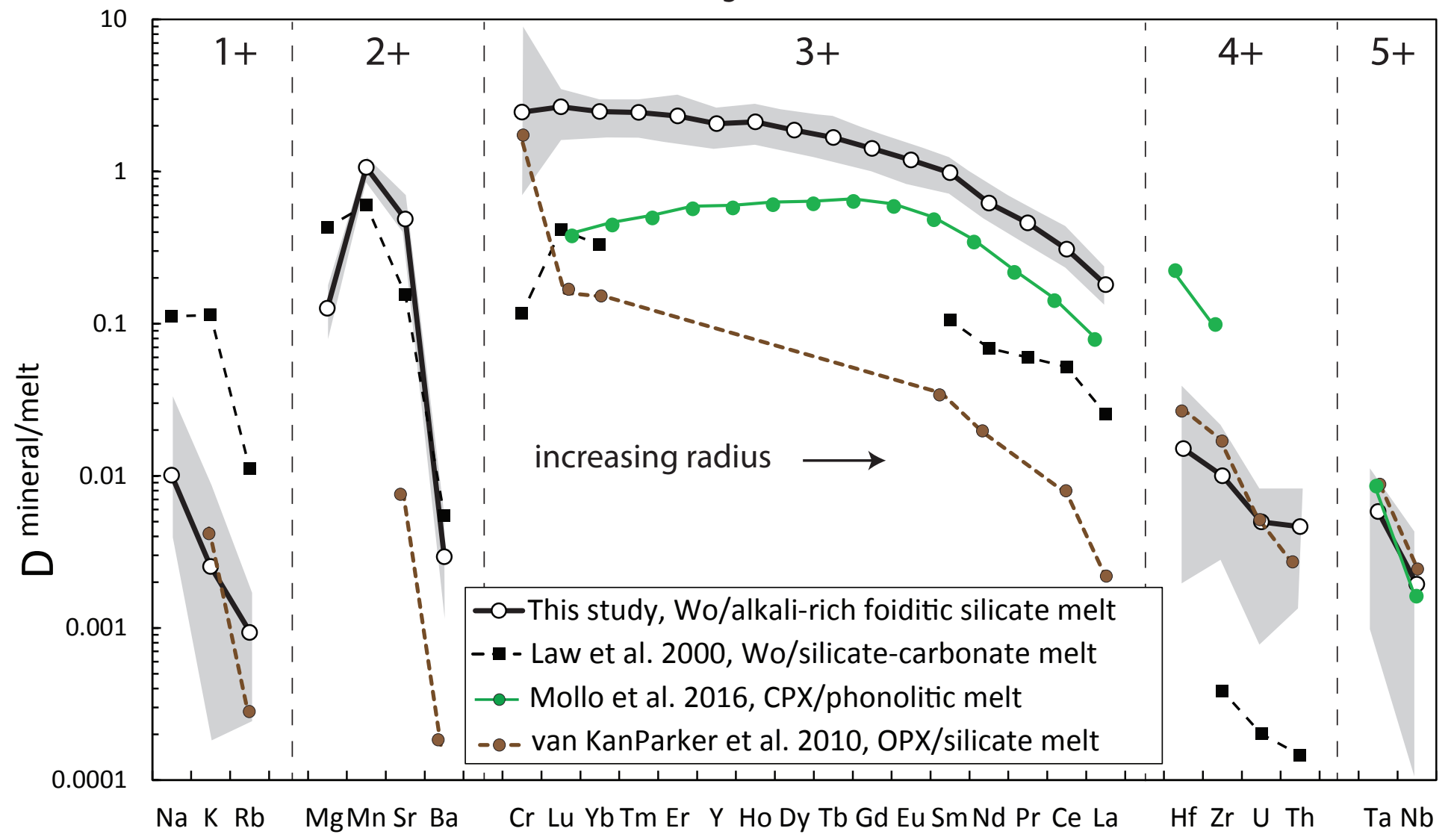


Figure 4
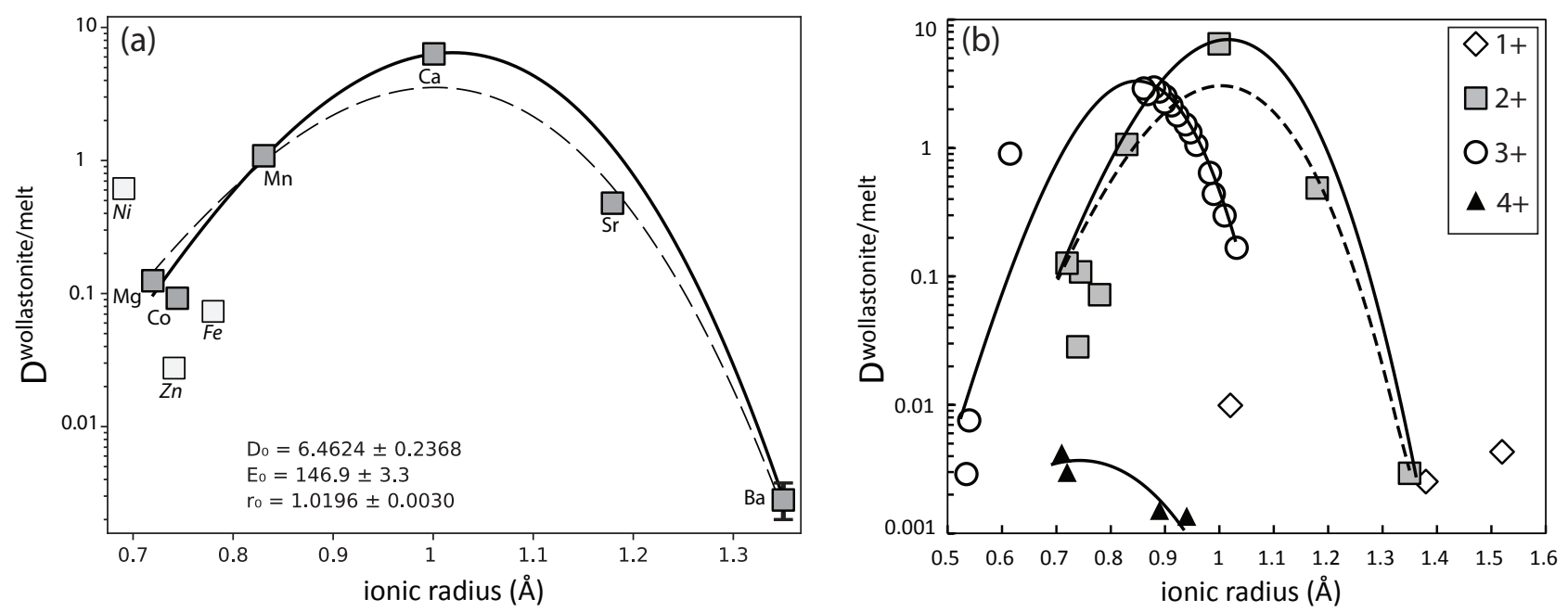
Figure 5

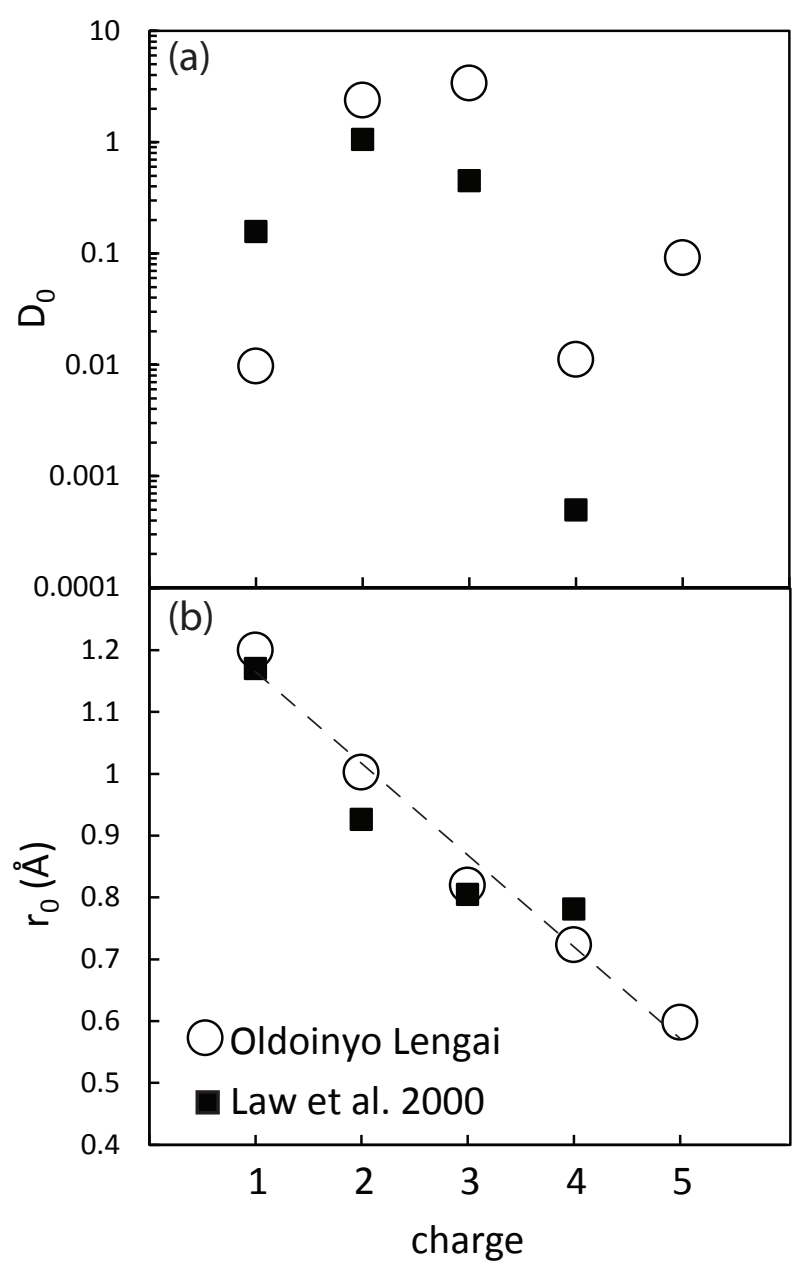


Figure 6

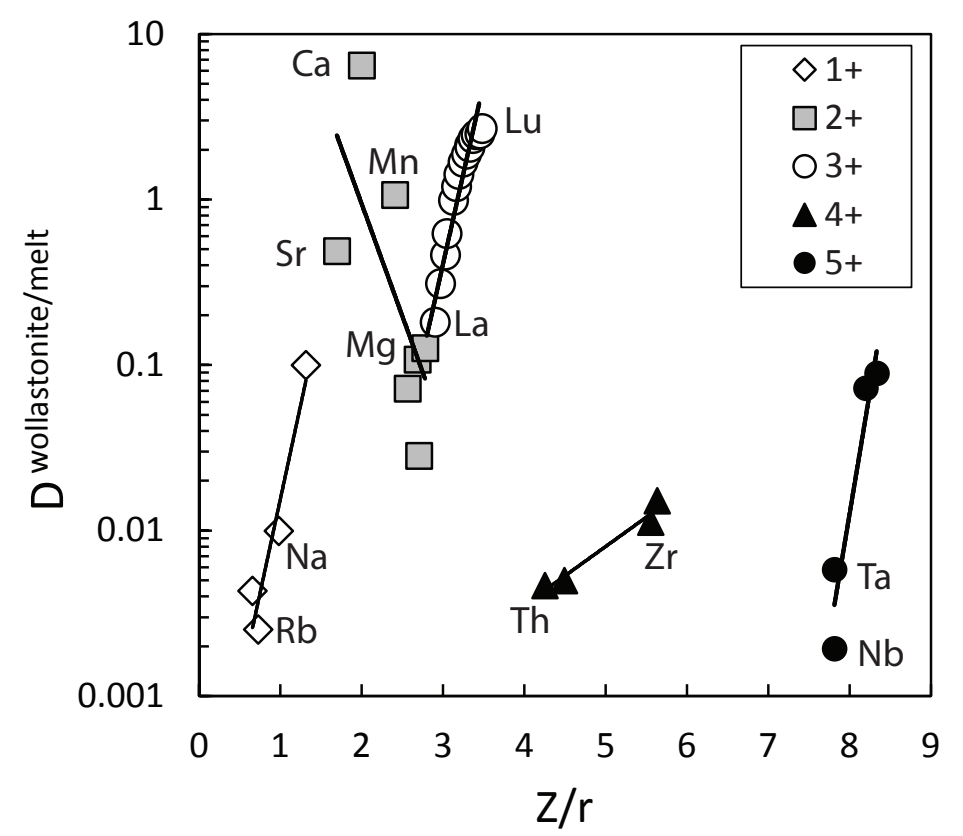

